\title{
Comparative Study of Chemical Composition and Biological Activity of Yellow, Green, Brown, and Red Brazilian Propolis
}

\author{
Christiane Schineider Machado, ${ }^{1}$ João Benhur Mokochinski, ${ }^{2}$ Tatiana Onofre de Lira, ${ }^{3}$ \\ Fátima de Cassia Evangelista de Oliveira, ${ }^{4}$ Magda Vieira Cardoso, ${ }^{5}$ \\ Roseane Guimarães Ferreira, ${ }^{5}$ Alexandra Christine Helena Frankland Sawaya, ${ }^{2}$ \\ Antonio Gilberto Ferreira, ${ }^{3}$ Cláudia Pessoa, ${ }^{4,6}$ Osmany Cuesta-Rubio, ${ }^{7}$ \\ Marta Chagas Monteiro, ${ }^{5}$ Mônica Soares de Campos, ${ }^{1}$ and Yohandra Reyes Torres ${ }^{1}$ \\ ${ }^{1}$ Departamento de Química, Universidade Estadual do Centro-Oeste (UNICENTRO), 85040-080 Guarapuava, PR, Brazil \\ ${ }^{2}$ Departamento de Biologia Vegetal, Instituto de Biologia, Universidade Estadual de Campinas (UNICAMP), \\ 13083-862 Campinas, SP, Brazil \\ ${ }^{3}$ Departamento de Química, Universidade Federal de São Carlos (UFSCar), 13565-905 São Carlos, SP, Brazil \\ ${ }^{4}$ Departamento de Fisiologia, Universidade Federal do Ceará (UFC), 60430-160 Fortaleza, CE, Brazil \\ ${ }^{5}$ Programa de Pós-graduação em Ciências Farmacêuticas, Faculdade de Farmácia, Universidade Federal do Pará (UFPA), \\ Belém, PA, Brazil \\ ${ }^{6}$ Fundação Oswaldo Cruz (Fiocruz), 60180-900 Fortaleza, CE, Brazil \\ ${ }^{7}$ Unidad Académica Ciencias Químicas y la Salud, Universidad Técnica de Machala, 070151 Machala, Ecuador
}

Correspondence should be addressed to Yohandra Reyes Torres; ryohandra@yahoo.com

Received 29 March 2016; Accepted 16 June 2016

Academic Editor: Jose M. Prieto

Copyright (C) 2016 Christiane Schineider Machado et al. This is an open access article distributed under the Creative Commons Attribution License, which permits unrestricted use, distribution, and reproduction in any medium, provided the original work is properly cited.

\begin{abstract}
The chemical composition and biological activity of a sample of yellow propolis from Mato Grosso do Sul, Brazil (EEP-Y MS), were investigated for the first time and compared with green, brown, and red types of Brazilian propolis and with a sample of yellow propolis from Cuba. Overall, EEP-Y MS had different qualitative chemical profiles, as well as different cytotoxic and antimicrobial activities when compared to the other types of propolis assessed in this study and it is a different chemotype of Brazilian propolis. Absence of phenolic compounds and the presence of mixtures of aliphatic compounds in yellow propolis were determined by analysing ${ }^{1} \mathrm{H}$-NMR spectra and fifteen terpenes were identified by GC-MS. EEP-Y MS showed cytotoxic activity against human tumour strain OVCAR-8 but was not active against Gram-negative or Gram-positive bacteria. Our results confirm the difficulty of establishing a uniform quality standard for propolis from diverse geographical origins. The most appropriate pharmacological applications of yellow types of propolis must be further investigated.
\end{abstract}

\section{Introduction}

Propolis is a beehive product popularly used to treat or prevent several disorders such as wound infections and respiratory conditions [1]. The regular intake of propolis has been indicated in traditional medicine as a way to promote health and enhance human resistance to infections or malignant affections with no unwanted side effects.
Brazilian propolis was previously classified by Park et al. [2] who described twelve distinct groups of Brazilian propolis. Green propolis (type 12) from south-eastern Brazil is currently the most exported Brazilian propolis. Green propolis is rich in artepillin $\mathrm{C}$ and other prenylated phenolic compounds with potent antitumour properties [3]. A brown type of propolis is found in the southern regions of Brazil (states of Paraná and Santa Catarina) [1, 4]. Yellow propolis 
samples from northeast and south Brazil were found by Park et al. [5] and classified in group 1 from southern region and groups 9 and 11 from northeast. In addition, yellow propolis from Cuba was described by Cuesta-Rubio et al. [6]. A 13th type of Brazilian propolis was later identified as the red propolis from northeastern Brazil [7]. Trusheva et al. [8] showed that this red propolis was rich in phenolics, triterpenoids, isoflavonoids, and prenylated benzophenones and a naphthoquinone epoxide was isolated for the first time from a natural source. Since then, red Brazilian propolis has been the target of further investigation by several research groups [6, 7, 9-13]. Sawaya et al. [4] have also carried out several studies seeking to classify the Brazilian propolis based on their ESI-MS fingerprints and chemometric multivariate analysis.

Despite the great number of studies about Brazilian propolis, the chemical composition of propolis from the central-western region of Brazil has been scarcely investigated $[4,19]$. Neither the chemical composition nor the pharmacological properties of yellow Brazilian propolis have been described so far. In the current study, we investigated the chemical composition and cytotoxic and antimicrobial activities of a sample of yellow Brazilian propolis collected in the Pantanal ecosystem in Mato Grosso do Sul, Brazil. Moreover, four samples of typical Brazilian classes of propolis, green propolis from São Paulo (EEP-G SP), green propolis from Minas Gerais (EEP-G MG), red propolis from Bahia (EEP-R BA), brown propolis from Paraná (EEP-B PR), and a sample of yellow propolis from Cuba (EMP-Y Cuba), were included in the study, permitting the direct comparison with the chemical characteristics and pharmacological potency of yellow propolis.

\section{Experimental}

2.1. Propolis Samples and Extracts. Propolis was supplied by beekeepers from different states of Brazil: red propolis (Bahia), green propolis (São Paulo), yellow propolis (Mato Grosso do Sul), and brown propolis (Paraná). A sample of green propolis from the state of Minas Gerais was purchased in a local market. A sample of yellow propolis from Cuba was prepared as a methanol extract. All propolis samples were stored at $-18^{\circ} \mathrm{C}$ until extraction. Ethanol extracts of propolis (EEP) were prepared using $10 \mathrm{~g}$ of each propolis samples mixed with $100 \mathrm{~mL}$ of absolute ethanol. The mixture was stirred for one day under controlled speed $(160 \mathrm{rpm})$ at room temperature and then filtered. The filtrates were kept in freezer overnight (temperature of $-18^{\circ} \mathrm{C}$ ) and filtered again to remove waxes. Solvent from the extractive solutions was removed in a rotatory evaporator at $50^{\circ} \mathrm{C}$ to obtain the dry ethanol extracts of propolis (EEPs).

2.2. ${ }^{1} H$-NMR Analysis. Samples of EEPs for ${ }^{1} \mathrm{H}-\mathrm{NMR}$ analysis were prepared as follow: a mixture of $100 \mu \mathrm{L} \mathrm{D}_{2} \mathrm{O}$ (buffer phosphate $\mathrm{pH} 7.04$ ) and $600 \mu \mathrm{L} \mathrm{CD}_{3} \mathrm{OD}$ was added to $30 \mathrm{mg}$ of propolis extracts and sonicated for $15 \mathrm{~min}$. The mixture was centrifuged at $13000 \mathrm{rpm}$ for $20 \mathrm{~min}$ at room temperature. The supernatant $(600 \mu \mathrm{L})$ was transferred into an NMR tube of $5 \mathrm{~mm}$. Sodium-3-trimethylsilyl-2,2,3,3- $\mathrm{d}_{4}$ propionate (TMSP $0.324 \mathrm{mg} / \mathrm{mL}$ ) was used as internal reference. All NMR experiments were recorded at $298 \mathrm{~K}$ in a Bruker UltraShielding $^{\mathrm{TM}}$ Plus $600 \mathrm{MHz}$ spectrometer operating at 14.6 T, equipped with a TCI cryoprobe for $\mathrm{H}-\mathrm{C} / \mathrm{N}-\mathrm{D} .{ }^{1} \mathrm{H}$ NMR spectra were acquired using a noesy pulse sequence for presaturation on water resonance and spoil gradient during mixing time (noesygpprld, Bruker terminology). The parameters set in this sequence were $4.0 \mathrm{~s}$ for relaxation delay time, acquisition time of 3.99, data points of 140k, mixing time of $10 \mathrm{~ms}$, and 128 scans with a spectral window of $30 \mathrm{ppm}$. Spectra were processed by applying an exponential line broadening LB of 0.3 and manually phased trough Topspin 3.0 (Bruker Biospin).

2.3. UPLC-ESI(-)-MS/MS. The EEPs were analysed on a UPLC Acquity Chromatographer (Waters, Milford, USA) coupled with a TQD Mass Spectrometer (Micromass-Waters Manchester, England), with an Electrospray source (ESI). Fingerprints were obtained by direct injection of $5 \mu \mathrm{L}$ of extracts by flow infusion into the ESI source. Chromatographic separation was carried out in a $\mathrm{C}_{18} \mathrm{BEH}$ Waters Acquity analytical column $(50 \mathrm{~mm} \times 2.1 \mathrm{~mm}$ i.d., $1.7 \mu \mathrm{m}$ particle size) held at $30^{\circ} \mathrm{C}$. A linear gradient elution was carried out with mili-Q purified water containing $0.1 \%$ formic acid (solvent $\mathrm{A}$ ) and acetonitrile (solvent $\mathrm{B}$ ) at a flow rate of $0.2 \mathrm{~mL} / \mathrm{min}$. Elution started with $95 \%$ of solvent $\mathrm{A}$ and $5 \%$ of solvent B. A linear gradient was performed until $100 \%$ of solvent B in 9 min and this condition was held for $1 \mathrm{~min}$. Afterwards, the initial elution condition was reestablished in $2 \mathrm{~min}$, totalizing $12 \mathrm{~min}$ for the chromatographic run. ESI(-)MS and tandem ESI(-)-MS/MS were obtained under the following analytical conditions: capillary $-3.5 \mathrm{kV}$, cone $-30 \mathrm{~V}$, source, and desolvation temperature were 150 and $350^{\circ} \mathrm{C}$, respectively. For ESI(-)MS/MS, the energy for the collision induced dissociations (CID) was $25 \mathrm{~V}$. Data were acquired in the $m / z 100-700$ range. Diagnostic ions in the different propolis samples were identified by the comparison of their ESI(-)MS/MS dissociation patterns with authentic analytical standards and/or by comparison with fragmentation pattern from the literature.

2.4. GC-EIMS. An aliquot of dry yellow propolis extracts was dissolved in ethyl acetate at a concentration of $500 \mu \mathrm{g} / \mathrm{mL}$. Volume samples of $1 \mu \mathrm{L}$ were injected in the splitless mode into an AGILENT gas chromatograph (model 7890A GC System), coupled with a mass spectrometer operating in EI mode at $70 \mathrm{eV}$. A $5 \%$ phenyl 95\% dimethylpolysiloxane capillary column $(30 \mathrm{~m} \times 0.25 \mathrm{~mm}$ i.d., $0.25 \mu \mathrm{m}$ film thickness $)$ was held at $250^{\circ} \mathrm{C}$ for $1 \mathrm{~min}$ and then heated to $300^{\circ} \mathrm{C}$ at the rate of $5^{\circ} \mathrm{C} / \mathrm{min}$. The final temperature was maintained for $10 \mathrm{~min}$. Helium was used as the carrier gas. Injector and detector temperature was $230^{\circ} \mathrm{C}$ and $150^{\circ} \mathrm{C}$, respectively. Compounds were identified by searching against a database of mass spectra (NIST 2011 Mass Spectral Library, Agilent Technologies). 
2.5. Cytotoxicity Assays. The cytotoxicity of propolis extracts was evaluated against four human tumour cell lines: OVCAR8 (ovary carcinoma), HCT-116 (colorectal carcinoma), SF-295 (human glioblastoma), and LH-60 (promyelocytic leukemia) obtained from the National Cancer Institute (Bethesda, MD, USA). The general viability of cultured cells was determined by the reduction of the yellow dye 3-(4,5-dimethyl-2thiazolyl)-2,5-diphenyl-2H-tetrazolium bromide (MTT) to a blue formazan product, as previously described by Mosmann [20]. The tumour cells were maintained in RPMI 1640 medium, supplemented with $10 \%$ foetal bovine serum, $1 \%$ penicillin, and streptomycin at $37^{\circ} \mathrm{C}$ with $5 \% \mathrm{CO}_{2}$. For all experiments, cells were seeded at $0.1 \times 10^{6}$ cells $/ \mathrm{mL}$ (LH-60, OVCAR-8, and SF-295) and $0.7 \times 10^{5}$ cells $/ \mathrm{mL}$ (HCT-116) and incubated during $72 \mathrm{~h}$ with propolis extracts at $37^{\circ} \mathrm{C}$ with $5 \% \mathrm{CO}_{2}$. After centrifugation and solution removing, MTT solution was added and the plates were incubated and centrifuged and the solids dissolved in pure and sterile DMSO. The absorbance was measured in a plate spectrophotometer DTX-800 (Beckman Coulter) at $595 \mathrm{~nm}$. Investigation of the survival viability for nontumour cell line L929 (mouse fibroblast) was also carried out. DMSO (solvent) and doxorubicin (reference standard drug) were used as negative and positive controls, respectively.

2.6. Antibacterial Activity. Antibacterial activity was evaluated against the following standard strains: (i) Grampositive bacteria: Staphylococcus aureus (ATCC 6538) and Enterococcus faecalis (ATCC 29212) (ii) bacteria Gramnegative: Pseudomonas aeruginosa (ATCC 25853) and Escherichia coli (ATCC 8739). All samples were obtained from INCQS/FIOCRUZ (National Institute of Quality Control in Health, Brazil). Furthermore, one clinic isolate, methicillin-resistant Staphylococcus aureus (MRSA), was also applied as test organism and obtained from cultures of patient samples existing in the Public Hospital (Bacteriological Laboratory) of Belém city, Pará, Brazil.

All bacteria were previously seeded in Petri plates containing Mueller Hinton agar (Merck, Germany) and incubated at $35^{\circ} \mathrm{C}$ for 24 hours. For bacterial inoculum preparation, strains were grown to exponential phase in Mueller Hinton broth (Merck, Germany) at $37^{\circ} \mathrm{C}$ for $24 \mathrm{~h}$ and adjusted by diluting fresh cultures to turbidity equivalent to $0.5 \mathrm{McF}$ arland scale (approximately $2 \times 10^{8} \mathrm{CFU} / \mathrm{mL}$ ) and then diluted until $1 \times 10^{3} \mathrm{CFU} / \mathrm{mL}$, as described by Clinical and Laboratory Standards Institute [21]. Minimum inhibitory concentration (MIC) and minimum bactericidal concentration (MBC) assays were performed using the broth microdilution method in MHB [21]. MIC is defined as the lowest concentration of extract with no visible growth of the microorganism in the resazurin colorimetric assay. To determine MIC, propolis extracts were dissolved in DMSO at the highest concentration $(19000 \mu \mathrm{g} / \mathrm{mL})$ to be tested. A serial twofold dilution was made in a concentration range from 100 to $19000 \mu \mathrm{g} / \mathrm{mL}$ in $1 \mathrm{~mL}$ sterile test tubes containing MHB. For the microdilution test, the inoculum $(100 \mu \mathrm{L})$ containing $5 \times 10^{3} \mathrm{CFU} / \mathrm{mL}$ was added to each well and $100 \mu \mathrm{L}$ was transferred into consecutive wells. After $24 \mathrm{~h}$ of incubation, $15 \mu \mathrm{L}$ of resazurin $(1 \mu \mathrm{g} / \mathrm{mL})$, which was metabolically reduced by active cells to a colour derivative, was added to the wells to allow visual identification of metabolic activity [22]. After incubation, the development of a purple-pink colour was considered as the indicative of bacterial growth. Therefore, MIC was read as the lowest concentration of the extract where the purple-pink colour was not observed. To determine $\mathrm{MBC}, 10 \mu \mathrm{L}$ of broth was taken from each well and incubated in Mueller Hinton agar at $37^{\circ} \mathrm{C}$ for $24 \mathrm{~h}$ and for each bacterium. The MBC was defined as the lowest extract concentration that resulted in a colony count lower than three colonies per $\mathrm{mL}$ (99.9\% killing) or no bacterial growth, as described by de Quadros et al. [23]. Each test was performed in three replicates. Negative control consisted of $100 \mu \mathrm{L}$ of the bacterial inoculum and $100 \mu \mathrm{L}$ of DMSO. Chloramphenicol $(50 \mu \mathrm{g} / \mathrm{mL})$ and gentamicin $(10 \mu \mathrm{g} / \mathrm{mL})$ were used as positive controls for Gram-positive and Gramnegative bacteria, respectively.

2.7. Statistical Analysis. For chemometrics analysis of NMR a bucket table was created using AMIX Statistics software (version 3.9.7, Bruker Biospin). A bucket window of $0.04 \mathrm{ppm}$ was choosen for spectral binning and residual water signal $(4.90-5.00 \mathrm{ppm})$ and methanol $(3.29-3.33 \mathrm{ppm})$ were excluded together with noise regions prior bucketing process. Principal component analysis (PCA) was used in order to compare the qualitative chemical composition of the diferent types of propolis extracts from several states of Brazil. Statistical differences between experimental types of propolis were verified by ANOVA followed by Fisher and Tukey test at $95 \%$ significance $(p<0.05)$.

\section{Results and Discussion}

3.1. Qualitative Comparison of the Chemical Composition of Propolis Extracts by ${ }^{1} \mathrm{H}$ NMR, ESI(-)-MS, and LC-ESI(-)$M S / M S$. The qualitative profile of green, red, brown, and yellow propolis from different regions of Brazil and one yellow propolis from Cuba was evaluated first by ${ }^{1} \mathrm{H}$ NMR (Figure 1) and by ESI(-)-MS fingerprinting (Figure 2). The samples of Brazilian propolis showed clearly distinct ${ }^{1} \mathrm{H}$ NMR (Figure 1) and ESI(-)-MS (Figure 2) patterns, indicating different chemical composition. The most striking feature in the ${ }^{1} \mathrm{H}$ NMR spectrum of yellow propolis is the absence of signals from aromatic compounds and the most down field hydrogens are vinyl hydrogens at $\delta 5.0$ to $6.0 \mathrm{ppm}$. This indicates the lack of abundance of phenolics compounds that are typically present in the green, brown, and red types of Brazilian propolis. In Figure 1, solvent signal $\left(\mathrm{D}_{2} \mathrm{O} / \mathrm{CD}_{3} \mathrm{OD}\right)$ at $3.36-3.27 \mathrm{ppm}$ and the signal for the internal reference TMSP were excluded from NMR spectra for better graphic quality.

Through ${ }^{1} \mathrm{H}$-NMR technique, it is possible to verify the chemical class of only the most abundant compounds in the extracts, once NMR technique is quite susceptible to compound concentration. Chemometric analysis of ${ }^{1} \mathrm{H}$ NMR data clustered propolis samples into three groups (Figure 3): a group comprising the green propolis; a second group for 

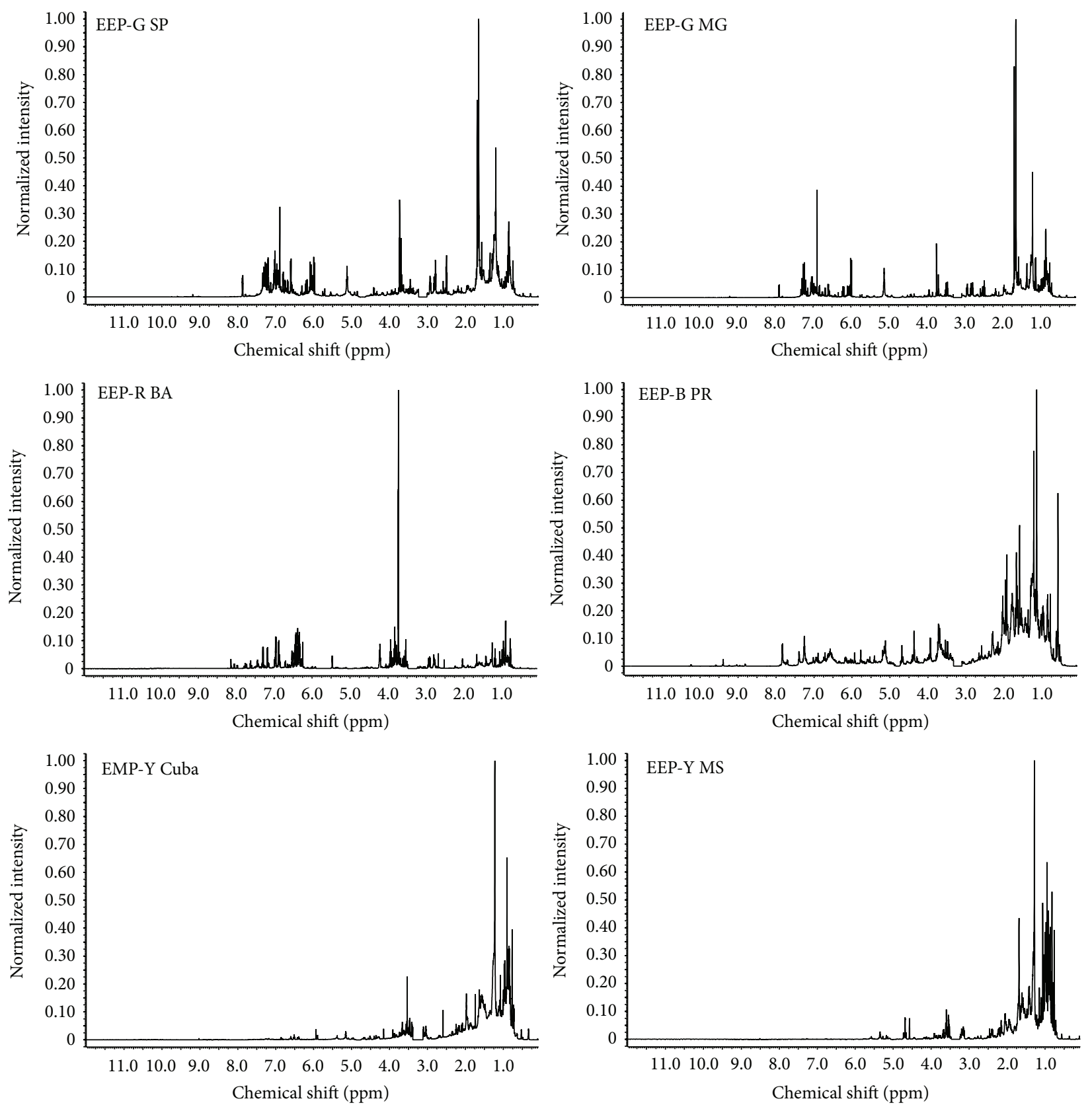

Figure $1:{ }^{1} \mathrm{H}$ NMR $\left(600 \mathrm{MHz}, \mathrm{CD}_{3} \mathrm{OD} / \mathrm{D}_{2} \mathrm{O}\right)$ of propolis extracts (solvent signal at $\delta 3.36-3.27$ and the signal for the internal reference TMSP were excluded from NMR spectra).

the brown and red propolis; and a third group for the yellow propolis. The Cuban and Brazilian yellow propolis were grouped due to the predominance of resonances at $\delta$ $0.7-1.1 \mathrm{ppm}$ and $\delta 1.23-1.32 \mathrm{ppm}$ characteristic of hydrogens bonded to $C s p^{3}$ in aliphatic compounds.

The six samples of propolis were also analysed by UPLC-ESI(-)-MS/MS to tentatively identify some of the ions observed by ESI(-)-MS fingerprinting (Figure 2). A total of twenty-nine known compounds were identified in green, red and brown Brazilian propolis and Cuban yellow propolis (Table 1). All these compounds have been previously identified in propolis and correspond to phenolic compounds, such as derivatives of benzoic and cinnamic acids, flavonoids and prenylated phenolic compounds, but labdanic terpenes were also found $[3,4]$.

\subsection{Chemical Composition of Yellow Brazilian Propolis by GC-} EIMS. The lipophilic nature of the constituents in yellow propolis made GC-MS the most suitable analytical technique to analyse the chemical composition of this type of propolis. 

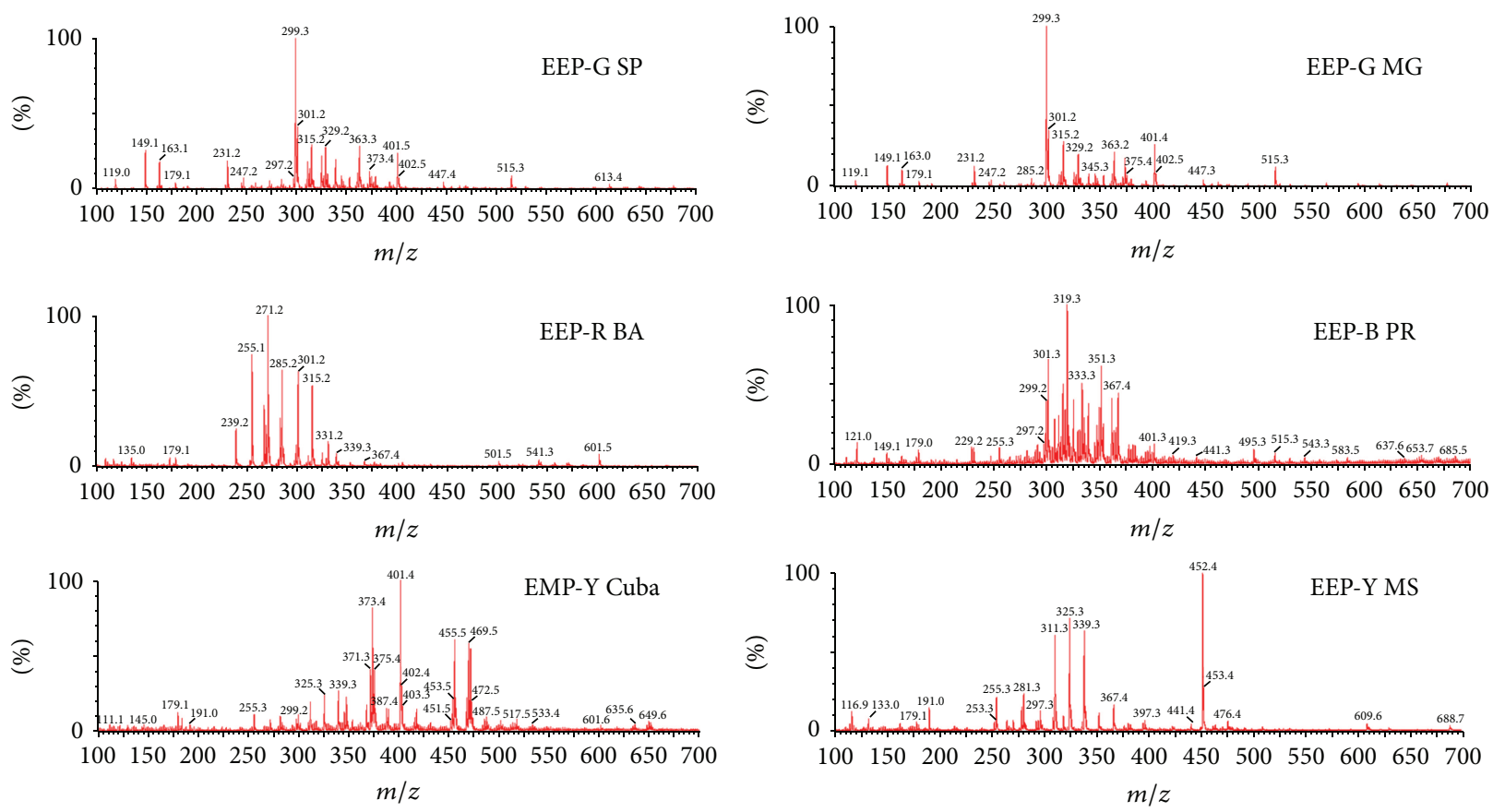

FIgURE 2: ESI(-)-MS fingerprints of propolis extracts.
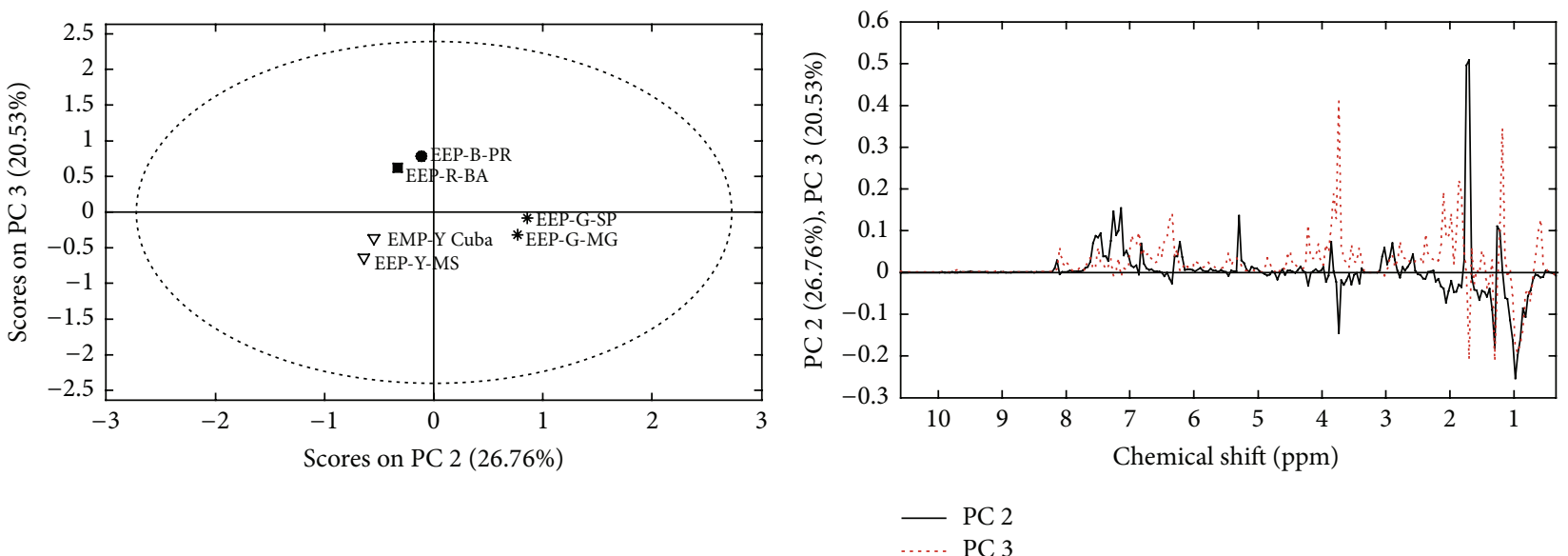

Figure 3: Principal component analysis of ${ }^{1} \mathrm{H}-\mathrm{NMR}$ data for extracts of propolis.

A total of fifteen triterpenoids were tentatively identified in the extract of yellow propolis (Figure 4) through comparison of their fragmentation profile with data from the NIST library and the literature data. At least three triterpenoids were already reported for Brazilian type 6 propolis (red colour), such as $\beta$-amyrin, lupeol, and olean-12-en-3-one $[8,18,24]$.

A study of the chemical composition of propolis produced in the state of Piauí (Brazil) resulted in the identification of six triterpenoids derived from cycloartane: isomangiferolic acid, mangiferolic acid, mangiferonic acid, ambonic acid, ambolic acid, and 24-methylene cycloartane$3 \beta, 26$-diol. The authors mentioned that these compounds were previously isolated from the stem bark of species of
Mangifera indica (Anacardiaceae) and suggested that this species could be the source of propolis from Piauí. Pentacyclic triterpenoids, such as lupeol, $\alpha$-amyrin and $\beta$-amyrin, and tetracyclic cycloartenol type, have shown significant antiinflammatory activity [25].

Hernández et al. [26] reported a quali-quantitative GCMS study of 19 samples of yellow Cuban propolis. Yellow Cuban propolis comprised two major groups: type A, rich in triterpenic alcohols and with the presence of polymethoxylated flavonoids as minor constituents, and type B, containing acetyl triterpenes as the main constituents [6]. Through GCMS compounds of low polarity were identified such as lanosterol, $\beta$-amyrone, $\beta$-amyrin, germanicol, lupeol, cycloartenol, 
TABLE 1: Propolis constituents identified by UPLC-ESI(-)-MS/MS.

\begin{tabular}{|c|c|c|c|c|}
\hline $\begin{array}{l}m / z \\
{[\mathrm{M}-\mathrm{H}]^{-}}\end{array}$ & Compound & Propolis origin & $\begin{array}{l}\text { ESI(-)-MS/MS } \\
m / z \text { (relative intensity\%) }\end{array}$ & Reference \\
\hline 151 & & SP & 150 (100); 147 (65); 127 (10); $121(15)$ & \\
\hline 163 & $p$-Coumaric acid & SP, Cuba, MG, PR & $163(20) ; 119(100)$ & a, $[4,14,15]$ \\
\hline 179 & Caffeic acid & SP, MG, PR & 179 (40); 135 (100); $116(50)$ & {$[14]$} \\
\hline 229 & $\begin{array}{l}\text { 2,2-Dimethyl-6-carboxyethenyl- } \\
\text { 2H-1-benzopyrane }\end{array}$ & SP, MG & $185(100) ; 168.9(50) ; 146(20)$ & a, [4] \\
\hline 231 & $\begin{array}{l}\text { 4-Hydroxy-3-prenylcinnamic } \\
\text { acid }\end{array}$ & SP, MG, PR & $231(15) ; 187(30) ; 132(100)$ & $\mathrm{a},[4,15,16]$ \\
\hline 233 & Viscidone & SP, MG, PR & $233(25) ; 188(100) ; 133(50) ; 132(85)$ & a \\
\hline 247 & $\begin{array}{l}\text { 3,4-Dihydroxy-5-prenylcinnamic } \\
\text { acid }\end{array}$ & SP, MG, PR & $247(40) ; 203(60) ; 148(100)$ & a, [16] \\
\hline 253 & $\begin{array}{l}\text { 2-Hydroxy-4- } \\
\text { methoxychalcone }\end{array}$ & BA & 253 (80); 237 (95); 209 (100); 161 (70); 136 (92) & {$[17]$} \\
\hline 253 & & SP, MG & $220(5) ; 162(20), 145(30) ; 118(100)$ & \\
\hline 255 & Liquiritigenin & BA & $255(35) ; 135(40) ; 119(100)$ & {$[7,9,17,18]$} \\
\hline 255 & & BA, Cuba & 255 (45); 135 (35); $119(100)$ & \\
\hline 255 & & MS & $\begin{array}{l}254(52) ; 209(100) ; 191(50) ; 153(62) ; 123(62) \text {; } \\
109(61)\end{array}$ & \\
\hline 285 & (3S)-Vestitone & BA, MG & $285(25) ; 269(33) ; 147(18) ; 109(100)$ & {$[18]$} \\
\hline 285 & Pinobanksin-5-methyl-ether & SP, MG & $285(100) ; 252(30) ; 163(45) ; 151(35) ; 136(50)$ & [14] \\
\hline 285 & Kaempferol & Cuba, BA & $285(83) ; 149(100) ; 122(85)$ & {$[14]$} \\
\hline 297 & & BA & $267(85) ; 205(100)$ & \\
\hline 299 & & $\mathrm{BA}$ & $299(40) ; 284(100)$ & \\
\hline 299 & Luteolin-methyl-ether & BA & $299(40) ; 284(100) ; 255(25) ; 227(30)$ & {$[14,15]$} \\
\hline 299 & Kaempferide & SP, Cuba, PR & 299 (100); 284 (90); 200 (30); $151(23)$ & {$[15,16]$} \\
\hline 299 & Artepillin C & SP, MG, PR & 299 (90); 255 (100); 200 (97) & a, $[4,16]$ \\
\hline 301 & Dihydrokaempferide & BA, SP, Cuba, MG, PR & $301(100) ; 283(5) ; 152(30)$ & a, [16] \\
\hline 315 & (3S)-Violanone & $\mathrm{BA}$ & $315(20) ; 108(100)$ & {$[18]$} \\
\hline 315 & Quercetin-3-methyl-ether & BA & $315(80) ; 300(55) ; 271(50) ; 243(100) ; 165(48)$ & a, [14] \\
\hline 315 & Isorhamnetin & SP, MG, PR & $315(100) ; 284(20) ; 252(30)$ & a, [15] \\
\hline 315 & $\begin{array}{l}\text { (3-4-Hydroxy-3-methyl-2- } \\
\text { butenyl-4-hydroxy-5-prenyl) } \\
\text { cinnamic acid }\end{array}$ & $\mathrm{SP}, \mathrm{MG}$ & 315 (100); 253 (90); $241(88) ; 198$ (98) & a \\
\hline 315 & $\begin{array}{l}\text { 3-Hydroxy-2,2-dimethyl-8- } \\
\text { prenylchromane-6-propenoic } \\
\text { acid }\end{array}$ & $\mathrm{SP}, \mathrm{MG}$ & $\begin{array}{l}315(75) ; 271(25) ; 253(20) ; 244 \text { (85); } 198 \text { (100); } \\
146(45)\end{array}$ & [15] \\
\hline 317 & & $\mathrm{BA}$ & $317(20) ; 270(23) ; 166(48) ; 109(100)$ & \\
\hline 317 & & SP, MG & 317 (25); $314(50) ; 241$ (100); $124(73)$ & \\
\hline 317 & & SP, MG & $317(10) ; 242(40) ; 200(100)$ & \\
\hline 317 & & SP & $317(45) ; 273(55) ; 160(100)$ & \\
\hline 317 & & MG & $317(40) ; 312(100) ; 253(50) ; 147(80)$ & \\
\hline 319 & & $\mathrm{BA}, \mathrm{PR}$ & $301(100) ; 193(25)$ & \\
\hline 319 & & MS & $319(20) ; 223(100)$ & \\
\hline 329 & & BA & $\begin{array}{l}329(30) ; 314(55) ; 299(100) ; 285(35) ; 271(100) ; \\
182(60)\end{array}$ & \\
\hline 329 & Quercetin-dimethyl-ether & SP, Cuba, MG, PR & 229 (100); 314 (70); 299 (42); $270(80) ; 227$ (25) & {$[14]$} \\
\hline 329 & Betuletol & SP, MG & $\begin{array}{l}329(85) ; 314(45) ; 299(100) ; 270(85) ; 257(90) \\
198 \text { (50); } 160(35)\end{array}$ & a \\
\hline 333 & Agathic acid & SP, MG, PR & $333(45) ; 314(40) ; 257(30) ; 245(35)$ & $\mathrm{a}$ \\
\hline
\end{tabular}


TABle 1: Continued.

\begin{tabular}{|c|c|c|c|c|}
\hline $\begin{array}{l}m / z \\
{[\mathrm{M}-\mathrm{H}]^{-}}\end{array}$ & Compound & Propolis origin & $\begin{array}{l}\text { ESI(-)-MS/MS } \\
m / z \text { (relative intensity\%) }\end{array}$ & Reference \\
\hline 347 & Agathic acid 15-methyl ester & SP & $247(70) ; 259(20) ; 187(100) ; 163(60) ; 146(80)$ & $\mathrm{a}$ \\
\hline 353 & & Cuba, MS & $353(40) ; 335(45) ; 151(40) ; 112(50)$ & \\
\hline 361 & 15-Acetoxy cupressic acid & MG, SP & $361(100) ; 317(70) ; 242(75) ; 159(45) ; 126(72)$ & a \\
\hline 363 & $\begin{array}{l}\text { 3-Prenyl-4- } \\
\text { dihydrocinnamoyloxy cinnamic } \\
\text { acid }\end{array}$ & SP, MG & 363 (20); 187 (80); 149 (100) & a, [15] \\
\hline 447 & $\begin{array}{l}\text { (E)-3-\{-4-hydroxy-3-[(E)-4-(2,3- } \\
\text { dihydrocinnamoyl } \\
\text { oxy)-3-methyl-2-butenyl]-5- } \\
\text { prenylphenyl }\}-2 \text {-propenoic } \\
\text { acid }\end{array}$ & SP, MG, PR & 447 (10); 297 (50); 197 (15); 149 (100) & $\mathrm{a},[16]$ \\
\hline 515 & 3,5-di-O-caffeoylquinic acid & SP, MG, PR & $515(25) ; 353(100) ; 173(30)$ & $\mathrm{a},[4,15]$ \\
\hline
\end{tabular}

${ }^{\mathrm{a}}$ Identification based on comparison with authentic analytical standards.

$\beta$-amyrin acetate, 24 -methylene-9,19-ciclolanostan-3 $\beta$-ol, $\alpha$ amyrin acetate, and lupeol acetate [26]. In our current report, all these compounds were found in the sample of yellow propolis from Pantanal (Mato Grosso do Sul, Brazil) demonstrating a similar chemical profile for the Cuban and Brazilian yellow propolis samples, which consequently formed a group in PCA (Figure 3).

3.3. In Vitro Cytotoxicity Assays. In preliminary screening of cytotoxic activity, the percentage of inhibition on three tumour cell lines was measured for each type of propolis (data not shown). Green samples (EEP-G SP and EEP-G MG) had low inhibition of all studied tumour cell lines, presenting low cytotoxic potential. Brown (EEP-B PR) and red (EEP-R BA) propolis had the highest cytotoxic potential with inhibition percentages greater than $75 \%$ in at least two tumour cell lines. Yellow propolis from Brazil (EEP-Y MS) showed high cytotoxic activity only against OVCAR-8 tumour cell, thus showing greater specificity against ovarian carcinoma.

Only extracts of red, brown, and yellow propolis, which showed inhibition percentages above $75 \%$ in at least one tumour cell, were considered for further experiments. An analytical curve obtained by linear regression, varying the concentration of extract of propolis and measuring inhibition of cell proliferation, enabled the calculation of the concentration required for each extract to inhibit $50 \%$ $\left(\mathrm{IC}_{50}\right)$ of tumour cells OVCAR-8 (ovary carcinoma), HCT116 (colorectal carcinoma), SF-295 (human glioblastoma), and LH-60 (promyelocytic leukemia) (Table 2). The highest concentration tested for each extract was $100 \mu \mathrm{g} / \mathrm{mL}$.

According to criteria established by the National Cancer Institute (NCI, USA), the $\mathrm{IC}_{50}$ threshold for extracts with promising cytotoxic activity value is $30 \mu \mathrm{g} / \mathrm{mL}$. The results showed that yellow propolis contains substances with cytotoxic effects. Brown propolis was effective against the four cell lines studied. To evaluate the degree of selectivity against tumour cell lines, $\mathrm{IC}_{50}$ was also investigated against the nontumour cell line L929 (mouse fibroblast) and a selective index (SI) was calculated as $\mathrm{IC}_{50}$ (nontumour cell)/ $\mathrm{IC}_{50}$ (tumour cell). The highest selectivity against all tumour cells was shown by red propolis especially against LH-60 (leukemia promyelocytic). da Silva Frozza et al. [17] also found that red propolis had selective cytotoxic activity for tumour cell lines. Yellow propolis had selective indexes between 0.91 and 1.84; however, only values of SI $\geq 2$ are considered significant [27]. Therefore, our results suggest that brown and red propolis and, to a lesser extent, yellow propolis may act in a selective way against tumour cells and show potential antitumour activity. We previously demonstrated that propolis extracts showed an in vivo antitumour activity in the experimental model Sarcoma 180 tumour cells with moderate toxicity effect at experimental exposure levels when compared to 5-FU [16]. Propolis has been a subject of intensive research, especially in the area of cancer, and its selectivity in vivo against tumours must be further investigated.

3.4. Antibacterial Activity. Samples of green (EEP-G MG and EEP-G SP) and red propolis (EEP-R BA) had high antibacterial activity against Gram-positive bacteria, mainly $S$. aureus (Table 3). Particularly, EEP-G SP showed excellent activity against S. aureus $(\mathrm{MIC}=159 \mu \mathrm{g} / \mathrm{mL})$, E. faecalis $(\mathrm{MIC}=$ $310 \mu \mathrm{g} / \mathrm{mL})$, and MRSA isolate (MIC $=630 \mu \mathrm{g} / \mathrm{mL})$.

As previously reported, the antimicrobial activity and chemical composition of propolis are directly associated with geographical location, biodiversity, bee species, and method and time of harvest $[28,29]$. The high antibacterial activity of propolis against Gram-positive bacteria, mainly strains of $S$. aureus and Enterococcus sp., has been widely described [2931]. However, previous studies have shown a wide variation in MIC and MBC values [29, 31]. Up to now, there are few studies on the antimicrobial activity of green and red propolis. A study of Brazilian red propolis from state of Alagoas reported that red propolis inhibited Streptococcus pyogenes and various Gram-negative bacteria, such as $P$. aeruginosa and E. coli with MIC values of 256 to $512 \mu \mathrm{g} / \mathrm{mL}$ [18]. Another study about Brazilian red propolis from the state of Alagoas reported MICs values of 50 to $100 \mu \mathrm{g} / \mathrm{mL}$ against $S$. aureus ATCC 25923 and Streptococcus mutans UA159 [10]. Regarding green propolis types, a propolis sample collected in São Paulo state inhibited $S$. mutans at concentrations 


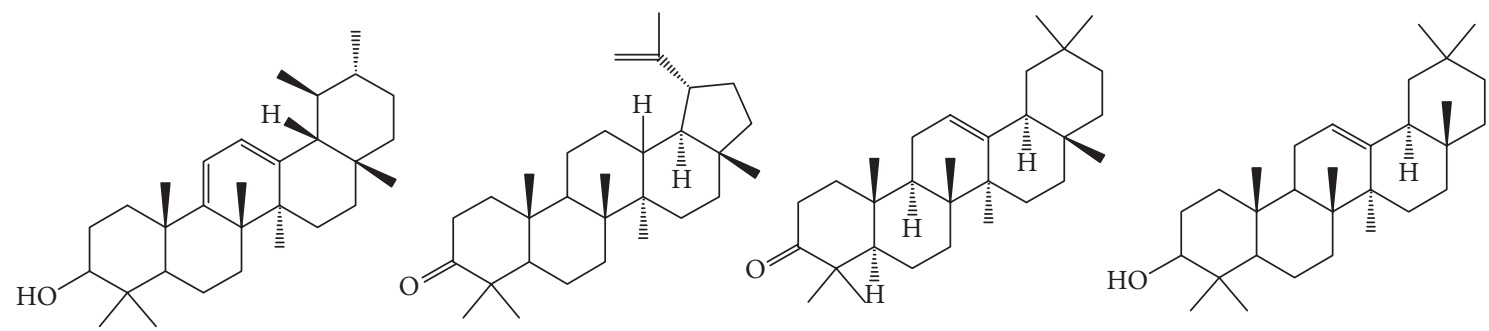

Ursa-9(11), 12-dien-3-ol (424)

Lup-20(29)-en-3-ona (424)

Olean-12-en-3-one (424)

$\beta$-amyrin (426)<smiles>CC(C)CCC[C@H](C)[C@H]1CC[C@]2(C)C3=CCC4C(C)(C)C(O)CC[C@]45CC35CC[C@]12C</smiles>

9,19-Cyclolanost-7-en-3-ol (426)<smiles>CC[C@H](C)[C@H]1CC[C@]2(C)C3=C(CC[C@]12C)[C@@]1(C)CCC(O)C(C)(C)C1CC3</smiles>

Lanosterol (426)

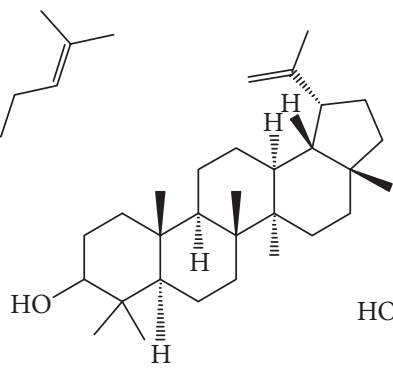

Lupeol (426)

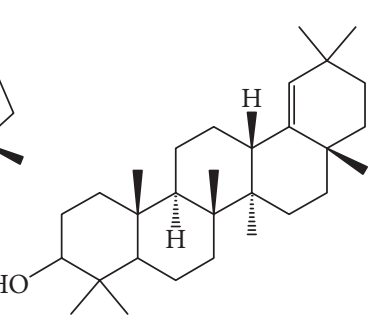

Olean-18-en-3-ol (426)<smiles>CC(C)=C(C)CC[C@@H](C)[C@H]1CC[C@]2(C)[C@H]1CC[C@@H]1[C@]3(C)CCC(O)C(C)C3=CC[C@]12C</smiles>

4,14-Dimethylergosta-5,24dien-3-ol (426)<smiles>CCC1C(C)(C)C(=O)CC[C@@]23C[C@]12CC[C@@]31[C@@H](C)CC[C@@H]1CC</smiles>

24-Metilene cycloartane3-ona (438)<smiles>CC(=O)OC1CC[C@]2(C)C3CC=C4[C@@H]5CC(C)(C)CC[C@]5(C)CC[C@]4(C)[C@H]3CCC2C1(C)C</smiles>

Olean-12-en-3-yl acetate (468)

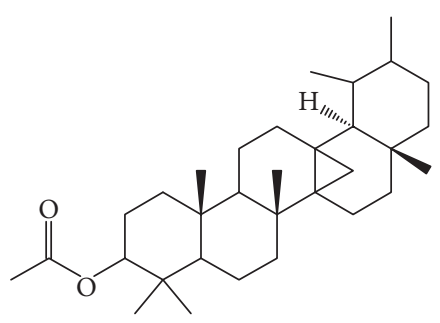

13,27-Cycloursan-3-ol- $(3 \beta, 13 \beta, 14 \beta)$ acetate (468)<smiles>C=C(CC)C(C)CC[C@H](C)[C@H]1CC[C@]2(C)C3CCC4C(C)(C)C(O)CC[C@]45C[C@@]35CC[C@]12C</smiles>

24-Methylcyclopentanol (440)

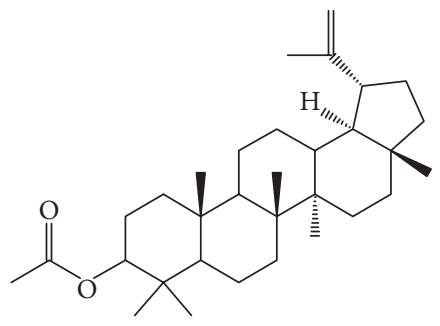

Lup-20(29)-en-3 $\beta$-ol acetate (468)

FIgUre 4: Compounds identified by GC-EIMS in the yellow propolis from Brazil.

of $400 \mu \mathrm{g} / \mathrm{mL}$ [32]. If compared with previous studies, our results showed that green propolis from São Paulo and Minas Gerais states was more effective at inhibiting Gram-positive bacteria, with MIC values of 159 to $310 \mu \mathrm{g} / \mathrm{mL}$, whereas Brazilian red propolis from Bahia state showed antibacterial action similar to other studies published. The higher antibacterial activity expressed by Brazilian green propolis may be attributed to its different chemical composition and its high concentration in flavonoids and aromatic acids such as galangin, kaempferol, pinostrobin, and pinocembrin which have shown high antibacterial effect, as reported by Grenho et al. [33]. In addition, Scazzocchio et al. also reported that some constituents such as flavonoids (kaempferide, quercetin, galangin, and pinocembrin), caffeic, benzoic, and 4-hydroxy-3,5-diprenylcinnamic acids may probably act by the inhibition of bacterial RNA polymerase but may also act on the local microbial membrane or cell wall, causing structural and functional damage, resulting in antimicrobial action [30].

On the other hand, our data showed that the two yellow propolis samples (EEP-Y MS and EMP-Y Cuba) were not active against Gram-negative bacteria or Gram-positive 


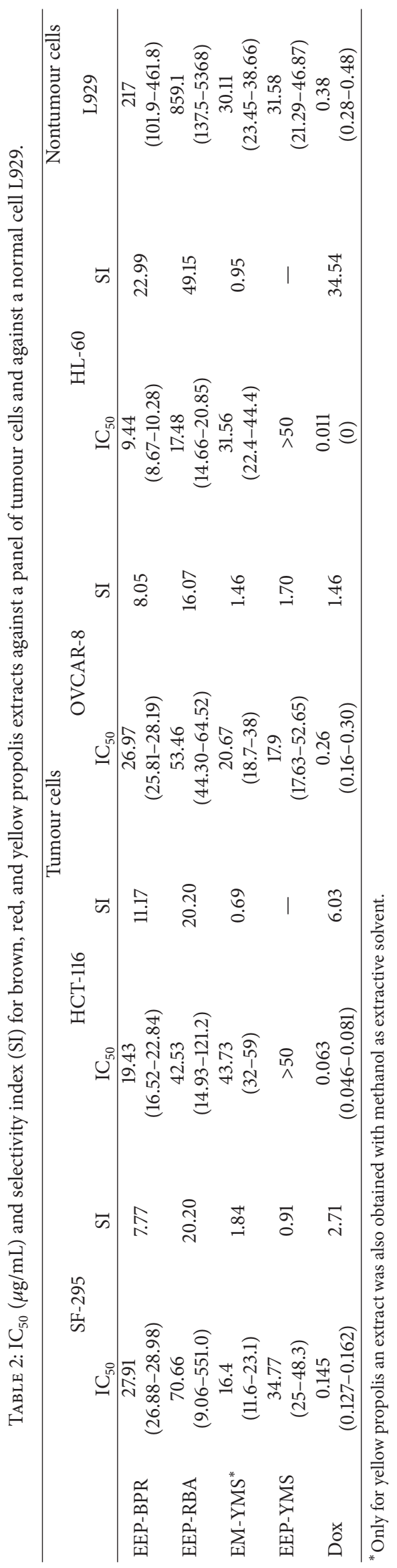


TABLE 3: Minimum inhibitory concentration (MIC) and minimum bactericidal concentration (MBC) for different extracts of propolis.

\begin{tabular}{|c|c|c|c|c|c|c|c|c|c|c|}
\hline \multirow{3}{*}{ Propolis } & \multicolumn{8}{|c|}{ Bacteria, MIC and $\mathrm{MBC} /(\mu \mathrm{g} / \mathrm{mL})$} & & \\
\hline & \multicolumn{2}{|c|}{ Staphylococcus aureus } & \multicolumn{2}{|c|}{$\begin{array}{l}\text { Methicillin-resistant } \\
\text { S. aureus (MRSA) }\end{array}$} & \multicolumn{2}{|c|}{ Enterococcus faecalis } & \multicolumn{2}{|c|}{$\begin{array}{l}\text { Pseudomonas } \\
\text { aeruginosa }\end{array}$} & \multicolumn{2}{|c|}{ Escherichia coli } \\
\hline & MIC & $\mathrm{MBC}$ & MIC & $\mathrm{MBC}$ & MIC & $\mathrm{MBC}$ & MIC & $\mathrm{MBC}$ & MIC & $\mathrm{MBC}$ \\
\hline EEP-Y MS & $>12,800$ & $>12,800$ & $>12,800$ & $>12,800$ & $>12,800$ & $>12,800$ & 6,400 & $>12,800$ & $>12,800$ & $>12,800$ \\
\hline EMP-Y Cuba & $>10,500$ & $>10,500$ & $>10,500$ & $>10,500$ & 5,020 & 10,500 & 5,020 & 6,400 & $>10,500$ & $>10,500$ \\
\hline EEP-B PR & $>19,900$ & $>19,900$ & $>19,900$ & $>19,900$ & 860 & $>1,730$ & $>13,900$ & $>13,900$ & $>13,900$ & $>13,900$ \\
\hline EEP-G MG & 200 & 400 & 400 & $>400$ & 400 & 800 & 6,450 & 12,900 & 6,450 & 12,900 \\
\hline EEP-G SP & 159 & 315 & 630 & $>630$ & 310 & $>630$ & 10,110 & 20,220 & 10,110 & 20,220 \\
\hline EEP-R BA & 390 & 780 & 780 & $>780$ & 780 & 1,570 & 6,300 & 12,600 & 6,300 & 12,600 \\
\hline Chloramphenicol & 50 & $>50$ & $>50$ & $>50$ & 50 & $>50$ & - & - & - & - \\
\hline Gentamicin & - & - & - & - & - & - & 4 & 10 & 10 & 10 \\
\hline DMSO & $>19,900$ & $>19,900$ & $>19,900$ & $>19,900$ & $>19,900$ & $>19,900$ & $>19,900$ & $>19,900$ & $>19,900$ & $>19,900$ \\
\hline
\end{tabular}

bacteria, with MIC values above $5020 \mu \mathrm{g} / \mathrm{mL}$. So far, there are no previous reports on the chemical composition of yellow propolis from Brazil and reports about their biological activities are also scarce. Park et al. [5] reported that samples of yellow propolis from Brazil were not active (or weakly active) against $S$. aureus. Additionally, yellow propolis samples had low antioxidant and anti-inflammatory activities. On the other hand, a previous report about yellow propolis from Cuba showed that extracts were able to inhibit $50 \%$ of $S$. aureus growth at low concentration, but no activity was observed against E. coli [34]. These yellow propolis samples from Cuba were abundant in triterpenoids and had a small proportion of phenolics and flavonoids if compared with green and red propolis.

\section{Conclusions}

The chemical composition of a yellow propolis from Mato Grosso do Sul/Brazil was analysed and its in vitro biological activity was assessed for the first time. This sample is rich in triterpenes and presents a different qualitative profile from other well-known types of Brazilian propolis. Yellow propolis showed cytotoxic activity against human ovarian carcinoma but was not active against Gram-negative or Gram-positive bacteria. Our results indicate that the Brazilian brown, red, and, to a lesser extent, yellow propolis inhibited, in a selective way, the growth of tumour cells and therefore show potential for anticancer therapy. Brazilian green propolis showed better antibacterial action, mainly against $S$. aureus and one multidrug-resistant clinical isolate (MRSA).

The results of the present study expand the knowledge about the chemical composition and biological activities of different chemotypes of propolis from Brazil, showing its variability and difficulty of standardization. Additionally, there is a need to investigate the most appropriate pharmacological applications for the yellow type of propolis due to its unique composition when compared to other types of Brazilian propolis.

\section{Competing Interests}

The authors declare no conflict of interests regarding the publication of this paper.

\section{Acknowledgments}

Financial support was provided by Finep (Fundo Paraná). Christiane Schineider Machado thanks CAPES and João Benhur Mokochinski thanks FAPESP (Grant no. 2013/213060) for doctoral fellowships. Alexandra Christine Helena Frankland Sawaya wishes to thank FAPESP and CNPq for the financial support. Authors also thank beekeepers who kindly supplied propolis samples.

\section{References}

[1] V. S. Bankova, S. L. de Castro, and M. C. Marcucci, "Propolis: recent advances in chemistry and plant origin," Apidologie, vol. 31, no. 1, pp. 3-15, 2000.

[2] Y. K. Park, S. M. Alencar, and C. L. Aguiar, "Botanical origin and chemical composition of Brazilian propolis," Journal of Agricultural and Food Chemistry, vol. 50, no. 9, pp. 2502-2506, 2002.

[3] L. M. C. Simões, L. E. Gregório, A. A. Da Silva Filho et al., "Effect of Brazilian green propolis on the production of reactive oxygen species by stimulated neutrophils," Journal of Ethnopharmacology, vol. 94, no. 1, pp. 59-65, 2004.

[4] A. C. H. F. Sawaya, D. M. Tomazela, I. B. S. Cunha et al., "Electrospray ionization mass spectrometry fingerprinting of propolis," Analyst, vol. 129, no. 8, pp. 739-744, 2004.

[5] Y. K. Park, M. Ikegaki, and M. S. de Alencar, "Classificação das própolis brasileiras a partir de suas características físicoquímicas e propriedades biológicas," Mensagem Doce, vol. 58, no. 9, pp. 3-7, 2000.

[6] O. Cuesta-Rubio, A. L. Piccinelli, M. C. Fernandez et al., "Chemical characterization of cuban propolis by HPLC-PDA, HPLCMS, and NMR: the Brown, Red, and Yellow cuban varieties of propolis," Journal of Agricultural and Food Chemistry, vol. 55, no. 18, pp. 7502-7509, 2007. 
[7] A. L. Piccinelli, C. Lotti, L. Campone, O. Cuesta-Rubio, M. Campo Fernandez, and L. Rastrelli, "Cuban and Brazilian red propolis: botanical origin and comparative analysis by high-performance liquid chromatography-photodiode array detection/electrospray ionization tandem mass spectrometry," Journal of Agricultural and Food Chemistry, vol. 59, no. 12, pp. 6484-6491, 2011.

[8] B. Trusheva, M. Popova, V. Bankova et al., "Bioactive constituents of Brazilian red propolis," Evidence-Based Complementary and Alternative Medicine, vol. 3, no. 2, pp. 249-254, 2006.

[9] A. Daugsch, C. S. Moraes, P. Fort, and Y. K. Park, "Brazilian red propolis-chemical composition and botanical origin," Evidence-Based Complementary and Alternative Medicine, vol. 5, no. 4, pp. 435-441, 2008.

[10] S. M. Alencar, T. L. C. Oldoni, M. L. Castro et al., "Chemical composition and biological activity of a new type of Brazilian propolis: red propolis," Journal of Ethnopharmacology, vol. 113, no. 2, pp. 278-283, 2007.

[11] S. Awale, F. Li, H. Onozuka, H. Esumi, Y. Tezuka, and S. Kadota, "Constituents of Brazilian red propolis and their preferential cytotoxic activity against human pancreatic PANC-1 cancer cell line in nutrient-deprived condition," Bioorganic \& Medicinal Chemistry, vol. 16, no. 1, pp. 181-189, 2008.

[12] C. Lotti, M. C. Fernandez, A. L. Piccinelli, O. Cuesta-Rubio, I. M. Hernández, and L. Rastrelli, "Chemical constituents of red Mexican propolis," Journal of Agricultural and Food Chemistry, vol. 58, no. 4, pp. 2209-2213, 2010.

[13] B. G.-C. López, E. M. Schmidt, M. N. Eberlin, and A. C. H. F. Sawaya, "Phytochemical markers of different types of red propolis," Food Chemistry, vol. 146, pp. 174-180, 2014.

[14] F. Pellati, G. Orlandini, D. Pinetti, and S. Benvenuti, "HPLCDAD and HPLC-ESI-MS/MS methods for metabolite profiling of propolis extracts," Journal of Pharmaceutical and Biomedical Analysis, vol. 55, no. 5, pp. 934-948, 2011.

[15] C. C. Fernandes-Silva, A. Salatino, M. L. F. Salatino, E. D. H. Breyer, and G. Negri, "Chemical profiling of six samples of Brazilian propolis," Quimica Nova, vol. 36, no. 2, pp. 237-240, 2013.

[16] A. A. Carvalho, D. Finger, C. S. Machado et al., "In vivo antitumoural activity and composition of an oil extract of Brazilian propolis," Food Chemistry, vol. 126, no. 3, pp. 12391245, 2011.

[17] C. O. da Silva Frozza, C. S. C. Garcia, G. Gambato et al., "Chemical characterization, antioxidant and cytotoxic activities of Brazilian red propolis," Food and Chemical Toxicology, vol. 52, pp. 137-142, 2013.

[18] A. A. Righi, T. R. Alves, G. Negri, L. M. Marques, H. Breyer, and A. Salatino, "Brazilian red propolis: unreported substances, antioxidant and antimicrobial activities," Journal of the Science of Food and Agriculture, vol. 91, no. 13, pp. 2363-2370, 2011.

[19] F. H. Fernandes, Z. da Rosa Guterres, W. S. Garcez, S. M. Lopes, J. Corsino, and F. R. Garcez, "Assessment of the (anti)genotoxicity of brown propolis extracts from Brazilian Cerrado biome in a Drosophila melanogaster model," Food Research International, vol. 62, pp. 20-26, 2014.

[20] T. Mosmann, "Rapid colorimetric assay for cellular growth and survival: application to proliferation and cytotoxicity assays," Journal of Immunological Methods, vol. 65, no. 1-2, pp. 55-63, 1983.

[21] Clinical and Laboratory Standards Institute (CLSI), Methods for Dilution Antimicrobial Susceptibility Tests for Bacteria that Grow
Aerobically, Approved Standard-Ninth Edition, CLSI document M07-A9, Clinical and Laboratory Standards Institute (CLSI), Wayne, Pa, USA, 2012.

[22] M. J. Q. F. Alves, F. F. Mesquita, M. Sakaguti, and A. C. Tardivo, "Hypocholesterolemic effect of propolis' caffeic acids," Revista Brasileira de Plantas Medicinais, vol. 10, no. 1, pp. 100-105, 2008.

[23] A. U. de Quadros, D. Bini, P. A. T. Pereira, E. G. Moroni, and M. C. Monteiro, "Antifungal activity of some cyclooxygenase inhibitors on Candida albicans: PGE2-dependent mechanism," Folia Microbiologica, vol. 56, no. 4, pp. 349-352, 2011.

[24] V. F. D. C. Ishida, G. Negri, A. Salatino, and M. F. C. L. Bandeira, "A new type of Brazilian propolis: prenylated benzophenones in propolis from Amazon and effects against cariogenic bacteria," Food Chemistry, vol. 125, no. 3, pp. 966-972, 2011.

[25] M. S. S. Silva, A. M. G. L. Citó, M. H. Chaves, and J. A. Lopes, "Triterpenóides tipo cicloartano de própolis de Teresina-PI," Química Nova, vol. 28, no. 5, pp. 801-804, 2005.

[26] I. M. Hernández, O. Cuesta-Rubio, M. C. Fernández et al., "Studies on the constituents of yellow cuban propolis: GCMS determination of triterpenoids and flavonoids," Journal of Agricultural and Food Chemistry, vol. 58, no. 8, pp. 4725-4730, 2010.

[27] M. Suffness and J. M. Pezzuto, Methods in Plant Biochemistry, Assays for Bioactivity, Academic Press, London, UK, 1991.

[28] E. M. Schmidt, C. D. S. Santos, D. Stock et al., "Effect of extraction solvent on antiradical activity of the obtained propolis extracts," Journal of Apicultural Research, vol. 53, no. 1, pp. 91100, 2014.

[29] E. M. Schmidt, D. Stock, F. J. G. Chada et al., "A comparison between characterization and biological properties of Brazilian fresh and aged propolis," BioMed Research International, vol. 2014, Article ID 257617, 10 pages, 2014.

[30] F. Scazzocchio, F. D. D’Auria, D. Alessandrini, and F. Pantanella, "Multifactorial aspects of antimicrobial activity of propolis," Microbiological Research, vol. 161, no. 4, pp. 327-333, 2006.

[31] T. Suleman, S. van Vuuren, M. Sandasi, and A. M. Viljoen, "Antimicrobial activity and chemometric modelling of South African propolis," Journal of Applied Microbiology, vol. 119, no. 4, pp. 981-990, 2015.

[32] D. P. D. S. Leitão, A. A. Da Silva Filho, A. C. M. Polizello, J. K. Bastos, and A. C. C. Spadaro, "Comparative evaluation of in-vitro effects of Brazilian green propolis and Baccharis dracunculifolia extracts on cariogenic factors of Streptococcus mutans," Biological and Pharmaceutical Bulletin, vol. 27, no. 11, pp. 1834-1839, 2004.

[33] L. Grenho, J. Barros, C. Ferreira et al., "In vitro antimicrobial activity and biocompatibility of propolis containing nanohydroxyapatite," Biomedical Materials, vol. 10, no. 2, Article ID 025004, 2015.

[34] L. Monzote, O. Cuesta-Rubio, M. C. Fernandez et al., "In vitro antimicrobial assessment of Cuban propolis extracts," Memorias do Instituto Oswaldo Cruz, vol. 107, no. 8, pp. 978-984, 2012. 


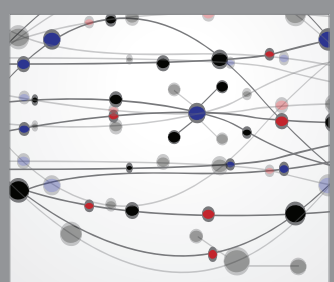

The Scientific World Journal
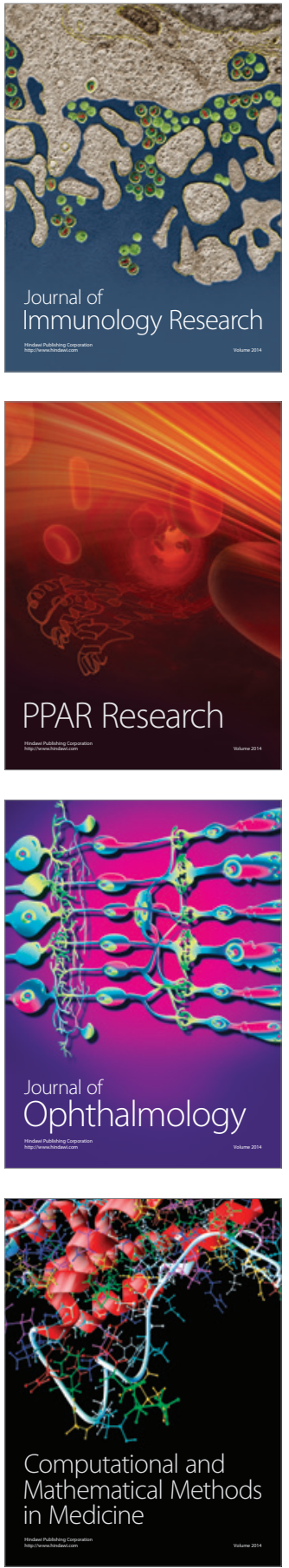

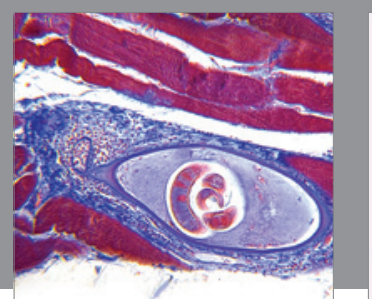

Gastroenterology Research and Practice

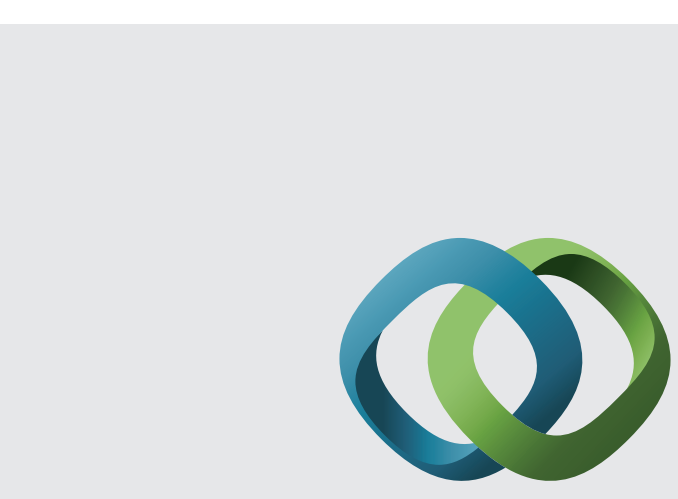

\section{Hindawi}

Submit your manuscripts at

http://www.hindawi.com
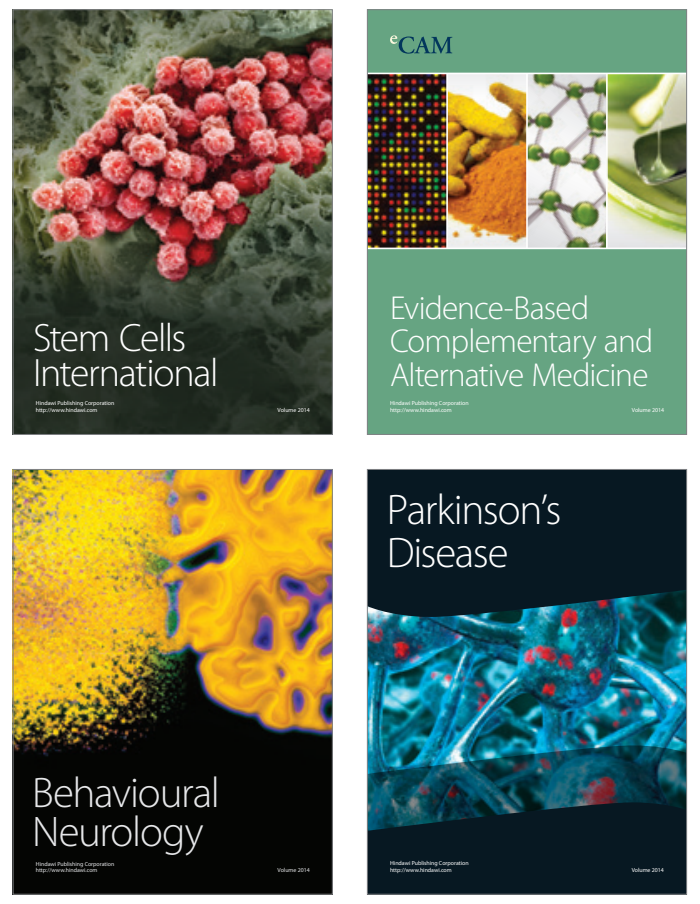
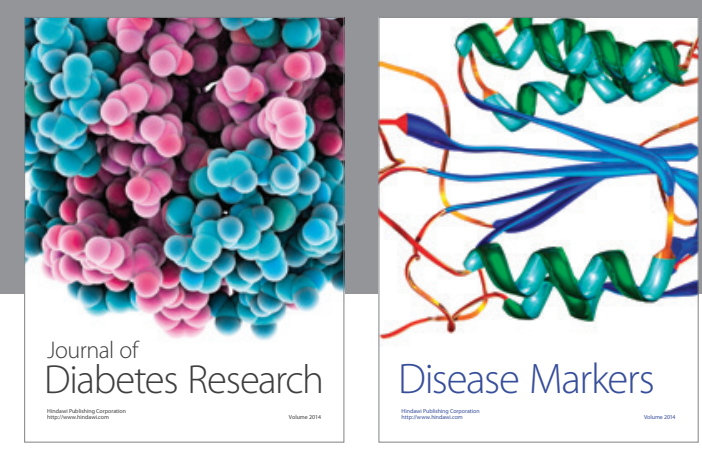

Disease Markers
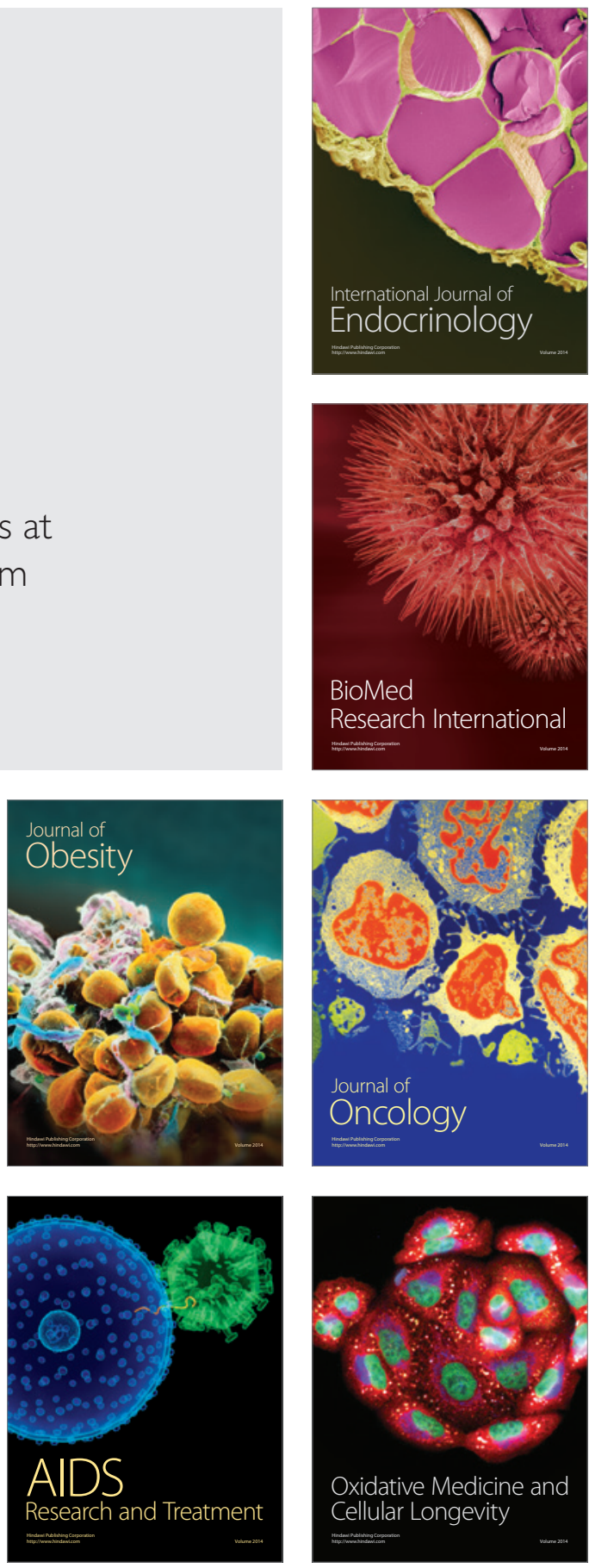